\title{
Pengaruh Model Discovery Learning Terhadap Kemampuan Berpikir Kritis Peserta Didik Pada Mata Pelajaran IPA Kelas V Tahun Pelajaran 2020/2021
}

\author{
Juniarti Fadila $^{1 *}$,Muhhamad Makki ${ }^{2}$ Husniati $^{3}$ \\ ${ }^{123}$ Pendidikan Guru Sekolah Dasar, FKIP,Universitas Mataram \\ *Corresponding Author: juniartifadila562@gmail.com
}

\begin{abstract}
Abstrcat
This study aims to determine the effect of discovery learning models on students' critical thinking skills in class V science subjects in SDN 19 Rabangodu Utara 2020/2021 academic year. The population is all fifth grade students of SDN 19 Rabangodu Utara. Data collection techniques use the test method of critical thinking skills of students who have previously tested the validity, reliability, level of difficulty and distinguishing power. Testing the prerequisites of the normality test analysis and homogeneity test. Technique of analyzing t-test data using polled variance. The results of data analysis with a significant $t$-test of $5 \%$ (0.05) showed a value of $t$ count, which was 3.314 and t_tabel of 2.0021 where the results showed that $t$ count $=3.314>t$ table $=2.0021$. It was concluded that the significant influence of the discovery learning model on students' critical thinking skills in class V science subjects in SDN 19 Rabangodu Utara academic year 2020/2021. Based on the N-Gain test, it is known that the improvement of students' critical thinking skills in class V science in SDN 19 Rabangodu Utara which uses the discovery learning model of 0.399 and is categorized as being in the experimental class. Whereas in the control class that applies the conventional learning method, the average increase in normalized gain is -0.028 and the category is low.
\end{abstract}

Keywords:Discovery Learning Model, Critical Thinking Ability

\begin{abstract}
Abstrcat
Penelitian ini bertujuan untuk mengetahui pengaruh model discovery learning terhadap kemampuan berpikir kritis peserta didik pada mata pelajaran IPA kelas V di SDN 19 Rabangodu Utara tahun pelajaran 2020/2021. Populasi adalah seluruh peserta didik kelas V SDN 19 Rabangodu Utara.Teknik pengumpulan data menggunakan metode tes kemampuan berpikir kritis peserta didik yang sebelumnya telah di uji validitas, reliabilitas, taraf kesukaran dan daya pembeda.Pengujian prasyarat analisis uji normalittas dan uji homogenitas. Teknik analisis data ttest dengan menggunakan polled varians. Hasil analisi data dengan t-test taraf signifikan $5 \%(0,05)$

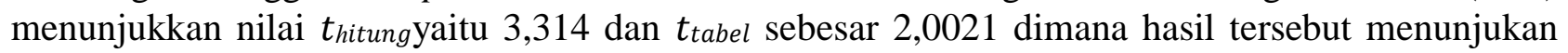
bahwa $t_{\text {hitung }}=3,314>t_{\text {tabel }}=2,0021$. Disimpulkan pengaruh yang signifikan model discovery learning terhadap kemampuan berpikir kritis peserta didik pada mata pelajaran IPA kelas V di SDN 19 Rabangodu Utara tahun pelajaran 2020/2021.Berdasarkan uji N-Gain diketahui bahwa peningkatan kemampuan berpikir kritis peserta didik pada mata pelajaran IPA kelas V di SDN 19 Rabangodu Utara yang menggunakan model discovery learning sebesar 0,399 dan berkategori sedang pada kelas eksperimen. Sedangkan pada kelas kontrol yang menerapkan metode pembelajaran konvensional didapat ratarata peningkatan gain ternormalisasi sebesar $-0,028$ dan berkategori rendah.
\end{abstract}

Kata Kunci : Model Discovery Learning, Kemampuan Berpikir kritis.

\section{PENDAHULUAN}

Ilmu Pengetahuan Alam (IPA) merupakan ilmu yang berkaitan dengan cara mencari tahu tentang alam secara sistematis, sehingga IPA tidak hanya penguasaan kumpulam pengetahuan yang berupa faktafakta, konsep, atau prinsip tetapi juga merupakan suatu proses 
penemuan.Pembelajaran IPA diharapkan mampu menjadi wahana bagi peserta didik untuk mengembangkan keterampilan, sikap dan nilai ilmiah, serta mempersiapkan menjadi warga negara yang berwawasan sains sebagai bekal hidup di masyarakat.Pelajaran IPA merupakan pelajaran yang menyenangkan karena berhubungan dengan kehidupan sehari-hari. Akan tetapi apa yang diharapkan umumnya berlainan dengan kenyataan, hal ini terjadi karena penggunaan model pembelajaran yang kurang tepat oleh guru dalam mengajar, Guru juga harus mencari alternatif pembelajaran mengenai model pembelajaran yang sesuai dan bagaimana memotivasi peserta didik untuk kreatif dan percaya diri serta mendorong peserta didik untuk memiliki kemampuan berpikir kritis.

Berpikir kritis merupakan merupakan suatu proses yang terarah dan jelas yang digunakan dalam kegiatan mental seperti memecahkan masalah, mengambil keputusan, menganalisis asumsi dan melakukan penelitian ilmiah. berpikir kritis merupakan suatu kegiatan berpikir untuk menentukan tindakan yang tepat dalam menganalisis fakta dan informasi menentukan strategi dalam pemecahan masalah. Definisi di atas juga menjelaskan bahwa berpikir kritis sebagai: (1) suatu sikap mau berpikir secara mendalam tentang masalah-masalah dan hal-hal yang berada dalam jangkauan pengalaman seseorang; (2) pengetahuan tentang metodemetode pemeriksaan dan penalaran yang logis; dan (3) semacam suatu keterampilan untuk menerapkan metode-metode tersebut. Berpikir kritis menuntut upaya keras untuk memeriksa setiap keyakinan atau pengetahuan asumtif berdasarkan bukti pendukungnya dan kesimpulan-kesimpulan lanjutan yang diakibatkannya.. Pada dasarnya peserta didik mempunyai kemampuan berpikir kritis dalam belajar misalnya keterampilan bertanya, hipotesis, klasifikasi, observasi (pengamatan) dan interpretasi, Tetapi keterampilan ini terkadang tidak berkembang dengan baik maka diperlukan adanya model pembelajaran yang mampu mengembangkan keterampilan berpikir krtisi peserta didik.
Model pembelajaran memegang peran sangat penting dalam proses pembelajaran, karena pada usia sekolah dasar perkembangan Kognitif mereka berada pada operasional konkret. Salah satu alternative model pembelajaran yang dapat diterapkan untuk mengembangkan kemampuan berpikir kritis yaitu model pembelajaran Discovery Learning. Dimana model pembelajaran ini merupakan usaha untuk memperoleh pengertian dan pemahaman yang lebih daripada inquiry.

Model discovery learning akan menciptakan suasana belajar yang lebih aktif Peserta didik tidak hanya menerima penjelasan dari guru, melainkan juga memecahkan masalah dengan mencari sendiri pengetahuannya melalui sumber-sumber yang ada tetapi tetap dengan bimbingan guru, dimana model discovery learning ini memiliki beberapa keuntungan. Keuntungan model discovery learning di antaranya untuk melatih peserta didik untuk berpikir tingkat tinggi salah satunya yaitu kemampuan berpikir kritis, membantu peserta didik untuk memperkuat dan menambah kepercayaan pada diri dengan proses penemuan sendiri, mengembangkan kemampuan berpendapat siswa. Tujuan dari penggunaan model pembelajaran adalah agar proses pembelajaran semakin bervariasi dan tidak membosankan, agar proses pembelajaran peserta didik menjadi aktif, dan membuat peserta didik semakin semangat dalam belajar karena mereka terlibat langsung dalam proses pembelajaran.

Menurut Hanafiah dan Suhana (2009:77) discovery merupakan suatu rangkaian kegiatan pembelajaran yang melibatkan seluruh kemampuan siswa secara maksimal untuk mencari dan menyelidiki secara sistematis, kritis, dan logis sehingga siswa dapat menemukan sendiri pengetahuan sikap dan keterampilan sebagai wujud adanya perubahan tingkah laku.

Model discovery learning ini akan membuat peserta didik lebih memahami, karena pembelajaran dilakukan dengan lebih konkrit dan realistis. Hal ini dapat dilihat dari penelitian yang dilakukan oleh Lestari bahwa 
model pembelajaran Discovery dapat berpengaruh signifikan terhadap kemampuan berpikir kritis siswa dalam pembelajaran IPA.hal ini disebabkan dalam setiap tahap pembelajaran Discovery siswa selalu dituntut untuk berpikir dan memecahkan masalah.Hasil penelitian ini menunjukkan perhitungan keterampilan berpikir kritis peserta didik kelas mengalami perbedaan dari pretest ke posttest.

Berdasarkan hasil observasi di SDN 19 Rabangodu Utara Kota Bima adalah begitu banyak peserta didik yang pasif, mereka cenderung duduk diam mendengarkan tanpa mampu mengembangkan informasi yang diperoleh. Kurangnya perhatian peserta didik terhadap materi pada saat proses pembelajaran juga tidak terlepas dari proses pembelajaran yang dilakukan oleh guru dan juga model pembelajaran yang digunakan oleh guru, Dalam hal ini guru harus mampu mencari alternatif pembelajaran menganai model pembelajaran yang sesuai dan bagaimana memotivasi peserta didik untuk kreatif dan percaya diri serta mendorong peserta didik untuk memiliki Kemampuan berpikir kritis.

Berdasarkan uraian diatas, Maka perlu dilakukan penelitian yang berkaitan dengan pengaruh model discovery learning terhadap kemampuan berpikir kritis peserta didik pada mata pelajaran IPA kelas V.

\section{METODE}

Penelitian ini merupakan penelitian Eksperimen jenis Quasi Eksperimental Tipe nonequivalen control group design. Eksperimen jenis Quasi Eksperimental merupakan desain penelitian yang memiliki kelompok kontrol dan kelompok eksperimen tidak dipilih secara random.Penelitian ini bertujuan untuk mengetahui ada atau tidak pengaruh model discovery learning terhadap kemampuan berpikir kritis peserta didik pada mata pelajaran IPA kelas V di SDN 19 Rabangodu Utara Tahun Pelajaran 2020/2021.Dalam penelitian ini populasinya adalah seluruh siswa kelas kelas V di SDN 19 Rabangodu Utara, Dalam penelitian ini pengambilan sampel dilakukan melalui teknik nonprobability sampling yaitu teknik pengambilan sampel yang tidak memberikan peluang/kesempatan sama bagi setiap unsur atau anggota populasi untuk dipilih menjadi sampel,Adapun jenis teknik sampling dari nonprobability sampling yang digunakan adalah sampling jenuh. Peneliti menggunakan teknik pengambilan sampel dengan teknik nonprobability sampling tipe sampling jenuh dengan alasan teknik sampling jenuh adalah teknik penentuan sampel dimana semua anggota populasi digunakan menjadi sampel .

Teknik pengumpulan data yang digunakan dalam penelitian ini adalah tes tes adalah instrumen atau alat untuk mengumpulkan data tentang kemampuan subjek penelitian dengan cara pengukuran, misalnya untuk mengukur kemampuan subjek penelitian dalam menguasai materi pelajaran tersebut; untuk mengukur kemampuan subjek penelitian dalam menggunakan alat tertentu, maka

Untuk uji coba instrument dilakukan di SDN 2 Tente dengan jumlah sampel 30 siswa. Terdapat 5 item soal yang valid dan 5 item soal yang tidak valid. Item soal yang valid, kemudian akan dijadikan sebagai item instrumen pada penelitian dan akan dianalisis. Sementara item soal yang tidak valid, tidak diambil sebagai instrumen penelitian dan tidak perlu di analisis.

Teknik analisis data dalam penelitian kuantitatif menggunakan statistik. Terdapat dua macam statistik yang digunakan untuk analisis data dalam penelitian, yaitu statistik deskriptif, danstatistik inferensialyang didalamnya terdapat uji normalitas, uji homogenitas, serta pengujian hipotesis statistik. Dalam penelitian ini, peneliti menggunakan statistik inferensial yang dilakukan untuk menguji hipotesis dengan menggunakan uji-t. Sebelum pengujian hipotesis, terlebih dahulu dilakukan uji normalitas dan uji homogenitas.

\section{HASIL DAN PEMBAHASAN PENELITIAN}

Hasil penelitian mengenai keterlaksanaan model discovery learning diperoleh dari data hasil observasi keterlaksanaan model discovery learning 
baikdari guru maupun peserta didik. Melalui hasil observasi diperoleh rekapitulasiskor terhadap kegiatan guru yang teramati berdasarkan sintaks model dan dapatdilihat persentase maupun kriteriaketerlaksanaan model discovery learning di dalam kelas selama 2 kali pertemuan dapat dilihat pada tabel berikut:

\begin{tabular}{|c|c|c|c|c|}
\hline Pertemuan & $\begin{array}{c}\text { Skor } \\
\text { Kegiatan } \\
\text { Guru }\end{array}$ & $\begin{array}{c}\text { Prsentase } \\
(\boldsymbol{\%})\end{array}$ & $\begin{array}{c}\text { Skor } \\
\text { Kegiatan } \\
\text { Siswa }\end{array}$ & $\begin{array}{c}\text { Presentase } \\
(\boldsymbol{\%})\end{array}$ \\
\hline I & 21 & 75 & 14 & 50 \\
\hline II & 23 & 82,14 & 17 & 60,71 \\
\hline
\end{tabular}

Pada Tabel 4.1 pertemuan pertama total skor $=21$ dengan skor maksimal 28, melalui perhitungan $\frac{21}{28} \times 100 \%$ maka diperoleh presentase sebesar $75 \%$ dengan kategori baik. Perhitungan yang sama juga berlaku untuk pertemuan kedua $\frac{23}{28} \times 100 \%=$ $82,14 \%$ dengan kategori sangat baik. Sedangkan data keterlaksanaan model pembelajaran oleh peserta didik Pertemuan pertama persentasenya $50 \%$ dengan kategori cukup baik dan pertemuan kedua persentasenya $60,71 \%$ dengan kategori baik. Adanya peningkatan hasil ini menunjukkan bahwa peserta didik mulai terbiasa mengikuti sintaks model discovery learning serta aktif dalam pembelajaran.

Tabel Nilai Pre-Test dan Post-Test Kemampuan Berpikir Kritis MasingMasing Indikator.

\begin{tabular}{|l|c|c|c|c|}
\hline \multirow{2}{*}{ Kelompok } & Tes & $\begin{array}{c}\text { Memberikan } \\
\text { Penjelasan } \\
\text { Sederhana }\end{array}$ & $\begin{array}{c}\text { Membangun } \\
\text { Keterampilan } \\
\text { Dasar }\end{array}$ & Menyimpulkan \\
\hline \multirow{3}{*}{ Konsperimen } & $\begin{array}{c}\text { Pre- } \\
\text { test }\end{array}$ & 13,75 & 14,75 & 12,58 \\
\cline { 2 - 5 } & $\begin{array}{c}\text { Post- } \\
\text { test }\end{array}$ & 21,75 & 18,25 & 15,58 \\
\hline & $\begin{array}{c}\text { Pre- } \\
\text { test }\end{array}$ & 14,75 & 13,25 & 14,16 \\
\cline { 2 - 5 } & $\begin{array}{c}\text { Post- } \\
\text { test }\end{array}$ & 18,75 & 16 & 12,58 \\
\hline
\end{tabular}

Data tersebut menunjukan bahwa terdapat peningkatan kemampuan berpikir kritis pada nilai pre-test dan post-test pada indikator memberikan penjelasan sederhana nilai rata-rata pre-test 13,75 meningkat menjadi 21,75 pada saat diberikan post-test, rata-rata nilai pre-test membangun keterampilan dasar 14,75 meningkat setelah diberikan post-test menjadi 18,25 dan pada indikator menyimpulkan nilai rata-rata pre- test peserta didik 12,58 meningkat menjadi 15,58 setelah dilakukan post-test.

Selain data hasil peningkatan kemampuan berpikir kritis pada masingmasing indikator, adapun data hasil tingkat kemampuan berpikir kritis peserta didik sebelum dan sesudah diberikan perlakuan dengan model discovery learning nilai ratarata pre-test kemampuan berpikir kritis peserta didik kelas eksperimen yaitu 43,7 dan kelas kontrol yaitu 54,16. Sedangkan nilai rata-rata post-test kemampuan berpikir kritis kelas eksperimen adalah 60,82 dan kelas kontrol yaitu 54,69. Adapun data hasil pretest dan post-test untuk kemampuan berpikir kritis pada kelas eksperimen dan kelas kontrol dapat dilihat pada tabel berikut :

\section{Tabel Data hasil Pre-test dan Post-test} Kemampuan Berpikir

\begin{tabular}{|c|c|c|c|c|c|}
\hline Kelompok & $\begin{array}{c}\text { Jumlah } \\
\text { Siswa } \\
(\mathbf{N})\end{array}$ & Tes & $\begin{array}{c}\text { Nilai } \\
\text { Terendah }\end{array}$ & $\begin{array}{c}\text { Nilai } \\
\text { Tertinggi }\end{array}$ & $\begin{array}{c}\text { Rata- } \\
\text { rata }\end{array}$ \\
\hline Eksperiman & 30 & Pre-test & 25 & 52,77 & 44,16 \\
\cline { 3 - 6 } & Post-test & 47,22 & 86,11 & 60,82 \\
\hline \multirow{2}{*}{ Kontrol } & \multirow{2}{*}{30} & Pre-test & 47,22 & 69,44 & 54,88 \\
\cline { 3 - 6 } & & Post-test & 36,11 & 75 & 53,6 \\
\hline
\end{tabular}

Berdasarkan Tabel di atas, dapat diinterpretasikan dalam diagram yang ditunjukkan pada Gambar di bawah ini.

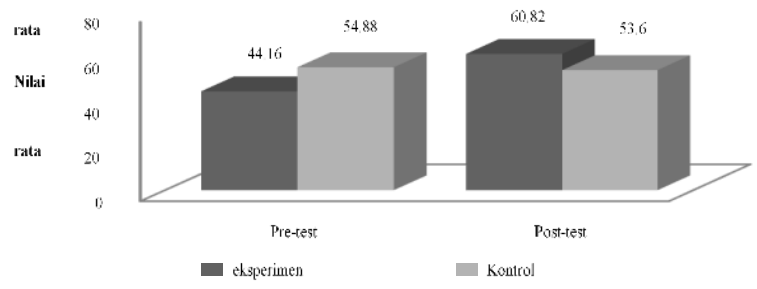

Dari Gambar diatas menunjukkan nilai rata-rata tes akhir kelas eksperimen sebesar 60,82 berkategori kritis sedangkan kontrol sebesar 54,16 berkategori kurang kritis.

\begin{tabular}{|c|c|c|c|}
\hline Kategori & $\begin{array}{c}\text { Skala } \\
\text { Perolehan }\end{array}$ & $\begin{array}{c}\text { Frekuensi } \\
\text { Pre-test }\end{array}$ & $\begin{array}{c}\text { Frekuensi } \\
\text { Post-test }\end{array}$ \\
\hline Sangat kritis & $81,25<x \leq 100$ & 0 & 1 \\
\hline Kritis & $\begin{array}{c}62,50<\mathrm{x} \leq \\
81,25\end{array}$ & 0 & 15 \\
\hline Kurang kritis & $\begin{array}{c}43,75<\mathrm{x} \leq \\
62,50\end{array}$ & 3 & 14 \\
\hline $\begin{array}{c}\text { Sangat } \\
\text { kurang kritis }\end{array}$ & $\begin{array}{c}25,00<\mathrm{x} \leq \\
43,75\end{array}$ & 27 & 0 \\
\hline
\end{tabular}

Data yang diperoleh melalui pengerjaan istrumen soal, memiliki kemungkinan skor tertinggi 86 dan skor 
terendah 25. Berdasarkan hasil perhitungandiperoleh rata-rata sebesar 60.82 dan simpangan baku sebesar 8,20. Berdasarkan rata-rata dan simpangan baku yang telah dihasilkan, maka dapat di buat klasifikasi kategori seperti tabel.

Berdasarkan tabel diatas, dapat dibuat histogram sebagai berikut :

\section{Histogram kemampuan berpikir kritis}

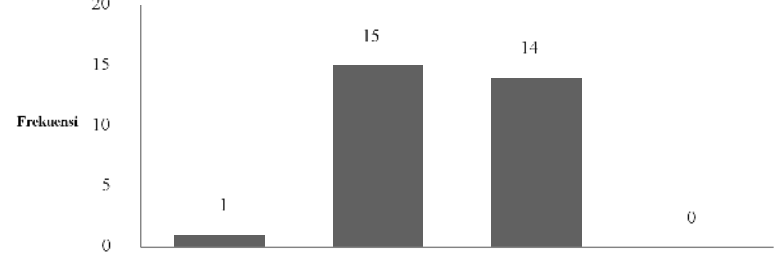

sangat kritis kritis kurang sangat kritis kurang kritis

Dengan melihat tabel dan histogram diatas, dapat diketahui bahwa frekuensi kategori sebaran data yang menunjukkan bagaimana kemampuan berpikir kritis peserta didik. Kemampuan berpikir kritis peserta didik setelah diberikan perlakuan dengan model pembelajaran discovery learning terdapat 0 peserta didik yang masuk dalam kategori memiliki kemampuan berpikir sangat kurang kritis, 14 peserta didik yang kategori kurang kritis, 15 kritis dan 1 peserta didik yang masuk dalam kategori sangat kritis. Dimana sebelum diberikan perlakuan jumlah peserta didik dalam kategori sangat kurang kritis 3 orang, kurang kritis 27 orang, kritis 4 dan sangat kritis 0 .

Dari uraian tersebut dapat dijelaskan bahwa peserta didik terbanyak berada pada kategori kritis yaitu sebanyak 15 orang dan jumlah peserta didik terendah berada pada kategori sangat kurang kritis terdapat 0 peserta didik. Oleh karena itu dapat disimpulkan bahwa berpikir kritis peserta kelas V di SDN 19 Rabangodu Utara berada pada kategori kritis.

Uji normalitas yang digunakan dalam penelitian ini adalah dengan menggunakan rumus Chi Kuardat pada taraf signifikansi 5\% $(\alpha=0.05$ dan derajat kebebasan $(\mathrm{dk})=\mathrm{k}-1)$. Kriteria pengujiannya adalah data terdistribusi normal apabila $\chi^{2}$ hitung $\leq \chi^{2}$ tabel, dan data tidak terdistribusi normal apabila $\chi^{2}$ hitung $\geq$ $\chi^{2}$ tabel
Hasil Uji Normalitas post- test kemampuan berpikir kritis Peserta didik

\begin{tabular}{cccc}
\hline Kelas & $\mathbf{X}^{\mathbf{2}}$ hitung & $\mathbf{X}^{\mathbf{2}}$ tabel & Kesimpulan \\
\hline Eksperimen & $\mathbf{5 , 5 6}$ & $\mathbf{1 1 , 0 7}$ & $\begin{array}{c}\text { Terdistribusi } \\
\text { normal }\end{array}$ \\
Kontrol & $\mathbf{4 , 5 8}$ & $\mathbf{1 1 , 0 7}$ & $\begin{array}{c}\text { Terdistribusi } \\
\text { normal }\end{array}$ \\
\hline
\end{tabular}

Grafik normalitas data post-test kelas kontrol dan kelas eksperimen dapat dilihat pada Gambar berikut:

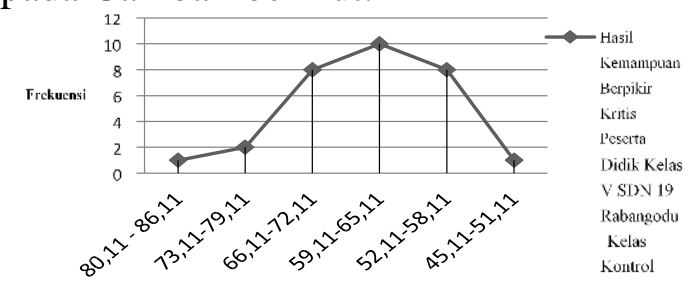

Berdasarkan Gambar diatas terdapat 6 interval kelas berdasarkan hasil kemampuan berpikir kritis (post-test) peserta didik pada kelas eksperimen, yaitu 80,11-86,11, 73,11$19,11,66,11-72,11,59,11-65,11,52,11-58,11$ dan $45,1151,11$. Terdapat 1 peserta didik yang mendapat nilai pada interval 80,11-86,11, 2 orang peserta didik mendapatkan nilai pada interval $73,11-79,11,8$ orang peserta didik mendapatkan nilai pada interval 66,11-72,11 10 orang peserta didik mendapat nilai pada interval 59,11-65,11, 8 orang peserta didik mendapat nilai pada interval 52,11-58,11 dan 1 orang peserta didik mendapat nilai pada interval 45,11-51,11.

Normalitas data kelas kontrol dapat dilihat pada Gambar berikut.

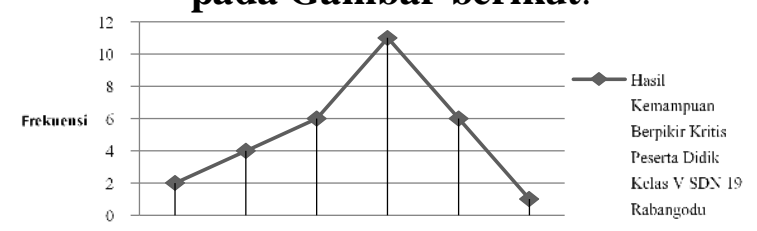

69-75 62-68 55-61 48-54 41-47 34-40 (Kelas Kontrol)

\section{Interval kelas}

Pada Gambar diatas terdapat 6 interval kelas berdasarkan hasil kemampuan berpikir kritis (post-test) peserta didik pada kelas eksperimen, yaitu 69-75, 62-68, 55-61, 48-54, 41-47 dan 34-40. Terdapat 2 peserta didik yang mendapat nilai pada interval 69-75, 4 orang peserta didik mendapatkan nilai pada interval 62-68, 6 orang peserta didik mendapatkan nilai pada interval 55-61, 11 orang peserta didik mendapat nilai pada 
interval 48-54, 6 orang peserta didik mendapat nilai pada interval 41-47 dan 1 orang peserta didik mendapat nilai pada interval 34-40.

Dari hasil pengujian normalitas data pre-test dan post-test siswa, kedua kelompok dapat dikatan homogen. Adapun hasil posttest kemampuan berpikir kritis pada kelas kontrol dan kelas eksperimen dapat dilihat pada tabel berikut:

\begin{tabular}{|c|c|c|c|}
\hline $\begin{array}{c}\text { Tabel Hasil Perhitungan } \\
\text { Homogenitas Pre-Test } \\
\text { Kemampuan berpikir } \\
\text { kritisKelompok }\end{array}$ & $\boldsymbol{F}_{\text {hitung }}$ & $\boldsymbol{F}_{\text {tabel }}(\alpha=0.05)$ & Uji Homogenitas \\
\hline Eksperimen Kontrol & 1,659 & 1,883 & Homogen \\
\hline
\end{tabular}

Tabel Hasil Perhitungan Homogenitas Post-Test Kemampuan berpikir kritis

\begin{tabular}{lccc}
\hline \multicolumn{1}{c}{ Kelompok } & Fhitung & $\begin{array}{l}\boldsymbol{F}_{\text {tabel }} \\
(\boldsymbol{\alpha}=\mathbf{0 . 0 5})\end{array}$ & $\begin{array}{l}\text { Uji } \\
\text { Homogenitas }\end{array}$ \\
\hline $\begin{array}{l}\text { Eksperimen } \\
\text { Kontrol }\end{array}$ & 1,31 & & \\
\hline
\end{tabular}

Dari hasil penghitungan homogenitas didapatkan $F_{\text {hitung }}<F_{\text {tabelatau }} 1,659<1,883$ pada pre-test dan $F_{\text {hitung }}<F_{\text {tabel }}$, atau 1,311 < 1,883 pada post-test dengan $\mathrm{db}$ pembilang $=$ 29 dan db penyebut $=29$ dari keterangan tersebut dapat disimpulkan bahwa kedua kelas (eksperimen dan kontrol) homogen dengan taraf signifikansi 5\% karena Fhitung $<$ Ftabel.

Setelah kedua persyaratan terpenuhi yaitu kedua kelas tersebut terdistribusi normal dan homogen.

Uji t dari post-test hasil kemampuan berpikir kritis dapat dilihat pada tabel berikut:

\begin{tabular}{|r|r|r|r|r|r|}
\hline Kelompok & $\begin{array}{c}\text { Jumlah Siswa } \\
\text { (n) }\end{array}$ & Rata - rata & \multicolumn{1}{c|}{ S2(varians) } & thitung & ttabel \\
\hline Eksperimen & 30 & 60,829 & 65,804 & 3,314 & 2,0021 \\
\hline Kontrol & 30 & 53,606 & 96,412 & & \\
\hline
\end{tabular}

Berdasarkan Tabel 4.8 dapat dilihat $t_{\text {hitung }}>t_{\text {tabel }}$ yaitu $3,314>2,0021$ pada taraf signifikan $5 \%$ dengan derajat kebebasan $(\mathrm{dk})$ $=\mathrm{n}_{1}+\mathrm{n}_{2}-2=30+30-2=58$. Hal ini menunjukkan bahwa terdapat pengaruh model discovery learning terhadap kemampuan berpikir kritis peserta didik pada mata pelajaran IPA kelas V di SDN 19 Rabangodu Utara tahun pelajaran 2020/2021. Serta berdasarkan uji N-Gain dapat diketahui bahwa adanya peningkatan kemampuan berpikir kritis peserta didik pada mata pelajaran IPA kelas V di SDN 19 Rabangodu Utara yang menggunakan model discovery learning sebesar sebesar 0,399 dan berkategori sedang padakelas eksperimen. Sedangkan pada kelas kontrol yang menerapkan metode pembelajaran konvensional didapat rata-rata peningkatan gain ternormalisasi sebesar $-0,028$ dan berkategori rendah.

\section{Pembahasan}

pengaruh model discovery learning terhadap kemampuan berpikir kritis peserta didik

Berdasarkan hasil penelitian yang dilakukan pada kelas $\mathrm{V}$ di SDN 19 Rabangodu Utara, diperoleh data frekuensi kategori nilai pre-test dan post-test kemampuan berpikir kritis peserta didik pada masing-masing indikator. Kemampuan berpikir kritis peserta didik setelah diberikan perlakuan dengan model pembelajaran discovery learning terdapat 0 peserta didik yang masuk dalam kategori memiliki kemampuan berpikir sangat kurang kritis, 14 peserta didik yang kategori kurang kritis, 15 kritis dan 1 peserta didik yang masuk dalam kategori sangat kritis. Dimana sebelum diberikan perlakuan jumlah peserta didik dalam kategori sangat kurang kritis 3 orang, kurang kritis 27 orang, kritis 4 dan sangat kritis 0. Oleh karena itu dapat disimpulkan bahwa kemampuan berpikir kritis peserta didik kelas V di SDN 19 Rabangodu Utara berada pada kategori kritis.

Berdasarkan hasil kemampuan berpikir kritis peserta didik (post-test) menunjukkan bahwa rata-rata kelas eksperimen lebih tinggi dari kelas kontrol yaitu 60,82 dan 53,6. Hasil kemampuan berpikir kritis tertinggi yang diperoleh kelas eksperimen adalah 86,11 dan terendah adalah 47,22. Sedangkan pada kelas kontrol nilai tertinggi 75 dan nilai terendah 36,11 , sehingga dapat dikatakan bahwa pembelajaran dengan model discovery learning berjalan dengan baik. Selanjutnya dilakukan analisis hipotesis dengan menggunakan rumus t-test polledvarians dengan taraf signifikansi $5 \%$ pada taraf kepercayaan $95 \%$ dan derajat kebebasan (dk) $=58$ peneliti memperoleh hasil $t_{\text {hitungyaitu }}$ 3,314 dan $t_{\text {tabel }}$ sebesar 2,0021 dimana

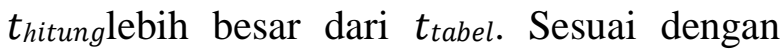


kriteria pengujian hipotesis menurut Sugiyono (2014: 237), jika $t_{\text {hitung }}>t_{\text {tabel }}$ maka hipotesis alternatif (Ha) dinyatakan diterimadan hipotesis nihil (Ho) dinyatakan ditolak, yang berarti bahwa ada pengaruh model discovery learning terhadap kemampuan berpikir kritis peserta didik pada mata pelajaran IPA kelas V di SDN 19 Rabangodu Utara tahun pelajaran 2020/2021. Perbedaan hasil tes akhir berdasarkan nilai rata-rata kedua kelas dan uji hipotesis ini menunjukkan bahwa penerapan model discovery learning berpengaruh terhadap kemampuan berpikir kritis. Hal tersebut karena model ini dapat melibatkan peserta didik secara optimal dalam proses pembelajaran, sehingga mereka aktif untuk mendapatkan pengetahuan melalui serangkaian kegiatan dalam model discovery learning yaitu menstimulasi/pemberian rangsangan, mengidentifikasi masalah, pengumpulan data, pengolahan data, pembuktian, menarik kesimpulan. Dimana kegiatan tersebut dapat melatih peserta didik untuk menemukan pengetahuannya sendiri. Keaktifan tersebut menyebabkan meningkatnya kemampuan berpikir kritis. Hal ini sesuai dengan apa yang di kemukakan oleh Glaser (dalam Fisher, 2009:3) berpikir kritis sebagai suatu sikap mau berpikir secara mendalam tentang masalah-masalah dalam hal-hal yang berada dalam jangkauan seseorang; pengetahuan tentang metodemetode pemeriksaan dan penalaran yang logis dan semacam suatu keterampilan untuk menerapkan metode-metode tersebut. Jadi, kemampuan berpikir kritis peserta didik akan berkembang jika selalu dihadapkan pada suatu permasalahan. Proses pembelajaran yang berlangsung pada kelas eksperimen dari kegiatan awal sampai kegiatan akhir menunjukkan adanya latihan kemampuan berpikir kritis. Pada awal kegiatan sebelum kegiatan dimulai, peserta didik dituntut untuk merumuskan hipotesis dengan bimbingan guru. Merumuskan hipotesis merupakan salah satu bagian kegiatan dari kemampuan berpikir kritis.

Jadi, berdasarkan pemaparan diatas dapat dikatakan bahwa model discovery learning dapat mempengaruhi kemampuan berpikir kritis peserta didik pada jenjang sekolah dasar yang dibuktikan dengan optimalnya hasil kemampuan berpikir kritis peserta didik, hal tersebut sesuai dengan hasil penelitian serta pengujian hipotesis pada penelitian ini, yang menunjukan bahwa penggunaan model discovery learning mempengaruhi kemampuan berpikir kritis peserta didik pada mata pelajaran IPA kelas V di SDN 19 Rabangodu Utara Tahun Pelajaran 2020/2021.

\section{KESIMPULAN}

Berdasarkan hasil penelitian, analisis data, dan pembahasan maka dapat disimpulkan hasil $t_{\text {hitung }}>t_{\text {tabel }}$ yaitu $t_{\text {hitung }}=$ 3,314 dan $t_{\text {tabel }}=2,0021$ jadi, dapat disimpulkan bahwa ada pengaruh model discovery learning terhadap kemampuan berpikir kritis peserta didik pada mata pelajaran IPA kelas V di SDN 19 Rabangodu Utara Tahun pejaran 2020/2021. Serta berdasarkan uji N-Gaun diperoleh peningkatan kemampuan berpikir kritis peserta didik yang menggunakan model discovery learning pada kelas eksperimen sebesar 0,399 berkategori sedang.

\section{Saran}

Hasil penelitian ini Diharapkan Dengan guru menerapkan model discovery learning dapat memperoleh wawasan tentang model pembelajaran aktif, dan memberi pengalaman baru kepada guru dalam mengembangkan kreatifitasnya, juga dalam mengembangkan alternatif pembelajaran yang dapat meningkatkan hasil belajar siswa khususnya pada mata pelajaran IPA dan juga bisa menjadi salah satu alternatif model pembelajaran yang dapat mengubah model pembelajaran yang pasif menjadi aktif serta memberikan kesempatan kepada peserta didik untuk mengembangkan potensi yang dimilikinya. Selain itu, dapat menjadi acuan untuk belajar IPA yang baik dan menyenangkan sehingga mendorong mereka untuk menggemari mata pelajaran tersebut.

\section{DAFTAR PUSTAKA}


Anderson, L.W. dan Krathwohl, D.R. 2001.Kata Kerja Operasional Revisi Taksonomi Bloom. (diakses tanggal 28 Mei 2018 pukul 15.20 Wita).

Arikunto, S. 2010. Prosedur Penelitian Suatu Pendekatan Praktek. Jakarta: Rineka Cipta.

Arikunto, S. 2013. Manajemen Penelitian. Jakarta: PT Rineka Cipta.

Azhar, A. 1996.Media Pembelajaran, Jakarta: PT Raja Grafindo Persada.

Djamarah, B, 2006. Strategi Belajar Mengajar. Jakarta: PT. Rineka Cipta.

Ennis, R. H. 1996. Critical Thinking. New Jersey. Prentice-Hall Inc.

Fahrudin. 2012. Thinking Skills Pengantar Menuju Berpikir Kritis. Yogyakarta: Suka Press.

Fisher, A. 2009.Berpikir Kritis, Sebuah Pengantar, Jakarta: Erlangga.

Gunawan, A. W. 2003. Genius Learning strategy pentunjuk praktis untuk menerapkan Acxelarated Learning. Jakarta: Gramedia Pustaka Utama.

Hanafiah, dan Suhana. 2009. Konsep Strategi Pembelajaran. Bandung: Refika Aditama.

Hosnan, M. 2014. Pendekatan Saintifik dan Kontekstual dalam pembelajaran Abad 21. Bogor: Ghaila Indonesia.

Huda, M. 2013. Model-model pengajaran dan pembelajaran. Pustaka Pelajar: Yogyakarta

Johnson. E. 2009. Contextual Teaching And Learning. (Edisi Terjemahan Ibnu Setiawan). Bandung: MLC.

Kesumawati, N. Reta, A.M. dan Sari, N. 2017. Pengantar Statistika Penelitian. Depok: Rajawali Press.

Kurniasih, I. dan Sani, B. 2014.Sukses Mengimplementasikan Kurikulum 2013. Yogyakarta: Kata Pena.

Lestari, T.W, Sudarti, dan Supriadi, B. 2015. Pengaruh Model Pembelajaran Discovery learning disertai media kartu masalah terhadap kemampuan berpikir kritis siwa dan hasil belajar siswa dalam pembelajaran IPA SDN 10 Jember.Jurnal pendidikan fisika FKIP UNEJ II . Vol 1, No. 1:1-4.
Mentari, W. 2015. Pengaruh Model Discovery Learning terhadap Kemampuan Berpikir Kritis dan Hasil Belajar Siswa dalam pembelajaran IPA SD pada materi pokok interaksi antar makhluk hidup dan lingkungan. Jurnal pendidikan biologi FKIP Universitas Lampung. Vol 4, No. 1:10-16

Munandar, U. 1999. Mengembangkat Bakat dan Kreativitas Anak Sekolah. Jakarta: PT. Gramedia

Nasution, S. 1982. Berbagai Pendekatan Dalam Proses Belajar Mengajar.Edisi Pertama.Jakarta : Bina Aksara.

Ngalimun. 2016. Strategi dan Model Pembelajaran. Ngaglik, Yogyakarta: Aswaja Pressindo.

Purwanto, N. 2013.Psikologi Pendidikan. Bandung: PT Remaja Rosdakarya.

Riduwan. 2014. Dasar-Dasar Statistika. Bandung: Alfabeta.

Riduwan.2013. Skala Pengukuran VariabelVariabel Penelitian. Bandung: Alfabeta.

Riduwan.2015. Belajar Mudah Penelitian untuk Guru-Karyawan dan Peneliti Pemula. Bandung: Alfabeta.

Samatowa, U. 2006. Bagaimana Membelajarkan IPA di SD. Jakarta: Depdiknas.

Sanjaya, W. 2013.Penelitian Pendidikan; Jenis, Metode, dan Prosedur.Jakarta: Kencana.

Santrock, J.W. 2009.Psikologi Pendidikan. Jakarta: Salemba Empat.

Setyosari, P. 2015. Metode Penelitian Pendidikan dan Pengembangan. Jakarta: Kencana Prenadamedia Group.

Sugiyono. 2010. Metode Penelitian Pendidikan Pendekatan Kuantitatif, Kualitatif, dan $R$ \& D. Bandung: Alfabeta.

Sugiyono. 2013. Metode Penelitian Pendidikan Pendekatan Kuantitatif, Kualitatif, dan $R \& D$. Bandung: Alfabeta. 


\section{- . 2014. Metode Penelitian}

Pendidikan Pendekatan Kuantitatif,

Kualitatif, dan $R$ \& D. Bandung:

Alfabeta.

- . 2017. Metode Penelitian Pendidikan Pendekatan Kuantitatif, Kualitatif, dan $R$ \& D. Bandung: Alfabeta.

Suprijono, A. 2016.Model-model Pembelajaran Emansipatoris. Yogyakarta: Pustaka Pelajar.

Susanto, A. 2013.Teori Belajar dan Pembelajaran.Jakarta: Kencana.

Sutrisno, H . 2015. Statistik. Yogyakarta: Pustaka Pelajar.

Trianto, 2014. Model Pembelajaran

$$
\begin{array}{ll}
\text { Terpadu: } & \text { Konsep, } \\
\text { Strategi } & \text { dan }
\end{array}
$$

Implementasinya dalam Kurikulum Tingkat Satuan Pendidikan (KTSP). Jakarta: Bumi Aksara

Widiasworo, E. 2017.Strategi dan Metode Mengajar Siswa di Luar Kelas.Yogyakarta : Ar-Ruzz Media.

Widoyoko, E. P.2017. Teknik Penyusunan Instrumen Penelitian. Yogyakarta: Pustaka Belajar.

Yuliati, D.I., Yulianti, D., dan Khanafiyah, S. 2011. Pembelajaran Fisika Berbasis Hands On Activities Untuk Menumbuhkan Kemampuan Berpikir Kritis dan Meningkatkan Hasil Belajar Siswa SMP, Jurnal Pendidikan Fisika Indonesia, 7, 2327.

Yuliawati, N., Panjaitan, R.L., dan Maulana. 2017.Pengaruh Model Discovery Learning Terhadap Kemampuan Berpikir Kritis Sisa Sekolah Dasar Pada Materi Perpindahan Energi Panas. Jurnal Program Studi PGSD UPI Sumedang. Vol.7, No.1:229. 